\title{
REDRESSING THE MUNICIPAL AFFAIRS WITH DIGITAL SPATIAL DATA TOWARD RESPONSIBLE LAND GOVERNANCE
}

\author{
Shamsuddin Ahmed
}

\begin{abstract}
This research offers a basis for spatial data management case in point that the land governance strategy denoting as a routine of digital spatial data legacy development is a major stipulation to the "land resources" and the "community services". Until 2015, Ontario's municipalities cover just $17 \%$ of its landmass where the municipal affairs pace complications in land use reckoned to the seven provincial plans. The Greater Golden Horseshoe Growth Plan often cloaks the multijurisdictional constraints, for example, the amendment of the municipal zoning ordinance, land registry and surveys, land claims and conciliations, and housing options and taxations. The emphasis is to contour: first, identification of the key attributes and entity-sets; second, structuring of the geo-relational database connecting the local activities at the dissemination areas; and finally, the thematic features of each municipality and their contiguity. On the contrary, responsible land governance in municipal affairs is obviously substance at least to the three central obligations such as approach in integrated land management, shared periphery negotiation for economic and environmental growth moratoria, and digital data automation properties and protocols. The suggestion is that a massive development of digital spatial data is necessary to readdress the municipal affairs toward responsible land governance ${ }^{l}$.
\end{abstract}

INTRODUCTION

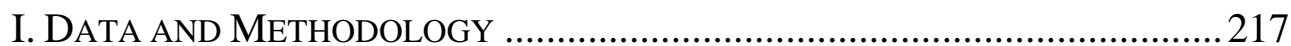

II. MUNICIPAL AFFAIRS AND RESPONSIBLE LAND GOVERNANCE ................222

\footnotetext{
${ }^{*}$ M.S. (environmental science), MPA (governance and public policy), MPPAL (public policy, administration and law), Graduate Diploma in Justice System Administration, Diploma in Development Panning, Certificate in Applied Digital Geography and GIS, is regular member of the Institute of Public Administration of Canada and research associate of York Centre for Public Policy and Law, York University, Canada. Research fields: Environmental Studies, Public Affairs, Public Policy, Public Administration, and Geographic Information Systems and Remote Sensing Data Analytics.

${ }^{1}$ This paper has been presented at the Annual World Bank Conference on Land and Poverty, The World Bank Group, 1818 H Street, NW Washington, DC 20433, March 20-24, 2017.
} 
A. Growth Management: A Route for Municipal Affairs.............. 226

B. Land Governance Shared Periphery as the Dimension of Growth

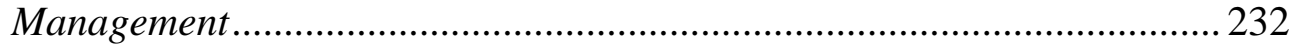

C. Approach to Integrated Land Management: Relative Intuitions of Municipal Affairs

III. Digital Spatial Data: MANAGEMENT Protocols AND PROPERTIES 243

A. Multi-party Negotiation for Economic and Environmental

Growth Moratoria.....

B. Digital Spatial Data Implementation Properties and Protocols....

\section{INTRODUCTION}

This research offers a basis for spatial data management case in point that the land governance strategy denoting as a routine of digital spatial data legacy development is a major stipulation to the land resources and the community services. Until 2015, municipalities in Ontario cover just 17 percent of its landmass where the municipal affairs pace complications in land use reckoned to the seven provincial plans. The Greater Golden Horseshoe Growth Plan often cloaks the multijurisdictional constraints, for example, the amendment of the municipal zoning ordinance, land registry and surveys, land claims and conciliation, and housing options and taxation.

Public policy agenda in municipal affairs are subject to the effective execution of the provincial policy regarding the "Ontario Planning Act" denoted from the "Ontario Planning Legislation" where the Ministry of Municipal Affairs and Housing (MMAH) chiefly refer the "Ontario Municipal Act". The Ontario Municipal Board (OMB) designated to the Environment and Land Tribunals Ontario (ELTO) is the authority for decision-making in land use and planning disputes resolution. It conforms the "Adjudicative Tribunals Accountability, Governance and Appointments Act, 2009"2 under the Ministry of the Attorney General. The procedural authority of the OMB is the "quasi-judicial" status with the adaptation of "Statutory Powers Procedure Act" by the Government of Ontario that sets out the general procedure for all tribunals conducting the hearings in land use and planning disputes in Ontario ${ }^{4}$. Local municipal agencies are

\footnotetext{
${ }^{2}$ Ministry of the Attorney General, S.O. 2009, C. 33, SCHED. 5 (2009), https://www.ontario.ca/laws/statute/09a33.

${ }^{3}$ The Government of Ontario, R.S.O. 1990, c. S.22 (1990), https://www.ontario.ca/laws/statute/90s22.

${ }^{4}$ Bruce W. Krushelnicki, A Practical Guide to the Ontario Municipal Board (Lexis Nexis

Canada, Inc. 2003).
} 
responsible for exercising "Zoning Bylaw", that controls the use of land in a municipal agency with necessary enactment or amendment. However, it contradicts the legal ideology in private interest to comply "the law exists and should be used to protect private property and institutions", then again $\mathrm{OMB}$ has a central role in the land use planning process in Ontario.

The emergence of responsible land governance appears to be the proper distribution of lands among the stakeholders and the community. This inference applies to the land claims, the ownership transfers, and the general accessibility under the provision of the provincial crown lands patent records to the land registry, and dispute resolutions, including the aboriginal land claims, entered into the modern-day treaty as a recent update. In 1973, the federal government's formal declaration emerged for beginning the negotiation of land claims. In government policy, land claims are two types ${ }^{7}$. One is the "comprehensive claims" that concerns the Aboriginal groups those have not signed treaties to settle land title as Crown has to assert ownership over the previously occupied lands. The other is "specific claims", not necesserily land-related, that have rendered from a comprehensive claim, or depends on the legal commitment of the government to the existing treaties that may appear due to grievances ${ }^{8}$. The federal government affords subsidies to the Aboriginal groups and the local community in Canada in the decisive situations.

The Ontario Ministry of Natural Resources and Forestry (MNRF) is responsible for Ontario Land Management such as the Crown Land and the Land Information Ontario (LIO), including municipal boundaries, soils type, road network, wetlands, provincial parks, and survey and registry. Commonly, the responsibility of "community services" relevant to provincial policy planning issue is in the MAHH while the MNRF maintains "land resources" information. Ontario has 85\% "Crown land" ${ }^{9}$, with overlapping a $2 \%$ underwater to some of the $17 \%$ (444) municipalities in total landmass while the total number of municipalities in 2011 was 443.

In viewing these issues, spatial data should have rendered to Ontario

\footnotetext{
${ }^{5}$ Ministry of Municipal Affairs and Housing, Citizens' Guide: Zoning By-Law, Provincial Planning Policy Branch, Government of Ontario (2010), http://www.mah.gov.on.ca/AssetFactory.aspx?did=11156.

${ }^{6}$ J. G. Chipman, A Law Unto ItSElf: How the Ontario Municipal Board Has Developed and APPLIEd Land Use Planning Policy 7 (Canada: University of Toronto Press, Inc. 2002).

${ }^{7}$ Indigenous and Northern Affairs Canada, Land Claims, Government of Canada, https://www.aadncaandc.gc.ca/eng/1100100030285/1100100030289.

${ }^{8}$ Frances WidDOwSON \& Albert Howard, DisRobing the Aboriginal Industry: The DeCEPTion BeHIND the Indigenous Cultural Preservation (Canada: McGill-Queen's University Press 2008).

${ }^{9}$ Ministry of Natural Resources and Forestry, Government of Ontario, Canada (2015), https://www.ontario.ca/page/crown-land.
} 


\section{REDRESSING THE MUNICIPAL AFFAIRS WITH 217}

One Spatial Information (OOSI) system to strengthening the seven provincial policy plans namely Greater Golden Horseshow Growth Plan, Greenbelt Plan, Niagara Escarpment Plan, Lake Simcoe Protection Plan, Central Pickering Plan, Parkway Belt West Plan, and Oakridge Moraine Conservation Plan. OOSI offered ascending the needs for information planning, and management development approach acceptable to the spatial and temporal distribution of baseline data those are indicative of the current trends in the Provincial Policy Planning initiatives, and all levels of municipal affairs in the priority of the community services.

Principally, the Ontario ministries aligned with the Community Services I\&IT Cluster (CSC) where the municipal affairs and housing had robust requirement on information planning, and management would need to appraise the policy planning and the economic indicators. CSC had an obtainable set-up of service delivery with geo-data management and mapping analysis noticeably to promote the institutional needs for spatial data business solution ultimately restructured to the concept of centralised geo-data governance allied to Land Resources I\&IT Cluster (LRC).

Digital Spatial Data strategy is imperative to the data organisational model referring the alternative model explicitly information design, integration and analysis of municipal affairs. This paper is structured in the following way. The Section I is a summary of data and methodology. Section II indicates extensive reviews of literature and insights about the responsible land governance needed in the municipal affairs. Section III offers a management framework of digital spatial data properties and protocols to redress the municipal affairs in responsible land governance.

\section{DATA AND METHODOLOGY}

The main sources of evidence that are publicly available are the literature reviews, government records and the web data portals. The study demonstrates here the topography of the Province of Ontario in Canada as explored (Figure 1). The term "topography" describes the physical features of earth's surface particularly in the forms of symmetrical topology in three digital characters: polygon, line and point. Relative case in point of topographical circumstances is tense from the evidence and lessons learned from the public service tenure. Data automation process needs structured information integration and analysis for policy initiatives development programs that are the topographical grasp of 173 single tier, 241 lower tier and 30 upper-level municipal agencies in the local government operational jurisdictions as of 2015. The majority of these municipalities are the centres 
of Ontario Growth management have economic planning and environmental conservations areas where the Greater Golden Horseshoe Plan, Niagara Escarpment Plan, and the Greenbelt Plan need revitalising from the multijurisdictional constraints (Figure 2).

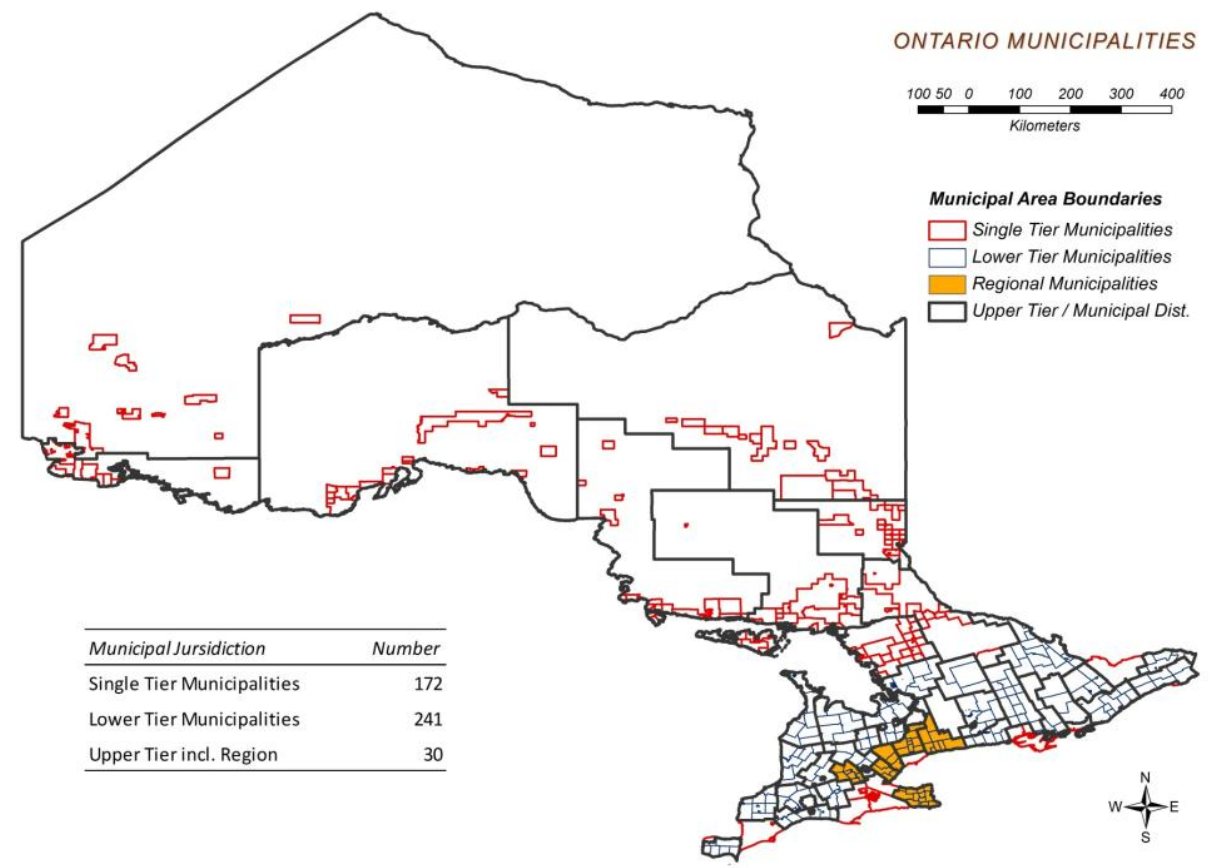

Figure 1 Topographical Coverage of Ontario Municipalities (Source: CSCMAH/MNR, 2010-2011). A lower-tier municipality forms part of an upper-tier municipality; a single-tier municipality (e.g., Toronto, Hamilton, and Barrie) is one that does not form part of an upper-tier municipality or a low-tier municipality. The upper tier is either a county or a regional municipality. An upper-tier municipality is created by amalgamating more than one lower-tier municipalities. Municipal responsibilities are distinct under the Municipal Act and other Provincial legislation and split between the upper-tier and lower-tier municipalities. See "Municipal Boundaries of Ontario 2004", Ministry of Municipal Affairs and Housing, Ministry of Natural Resources, and Statistics Canada. 


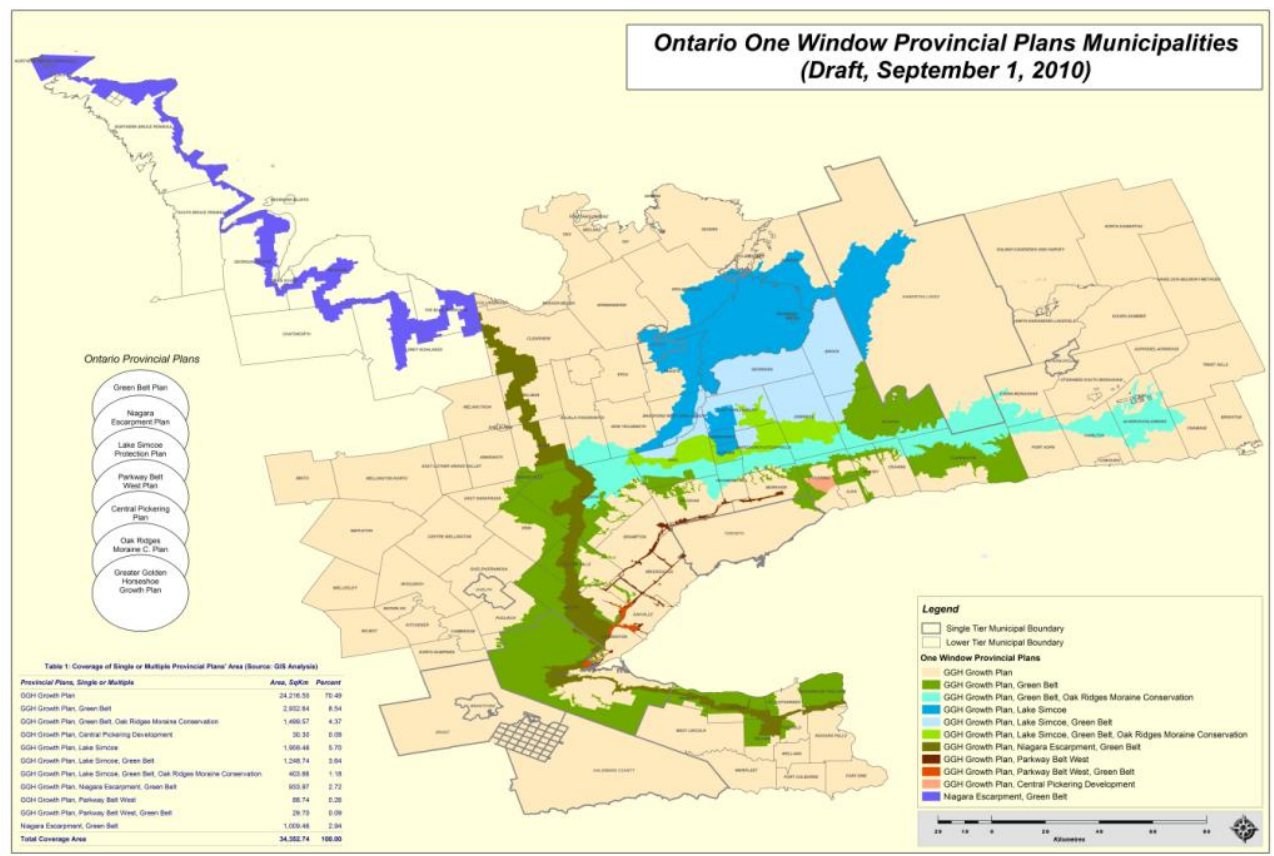

(a)

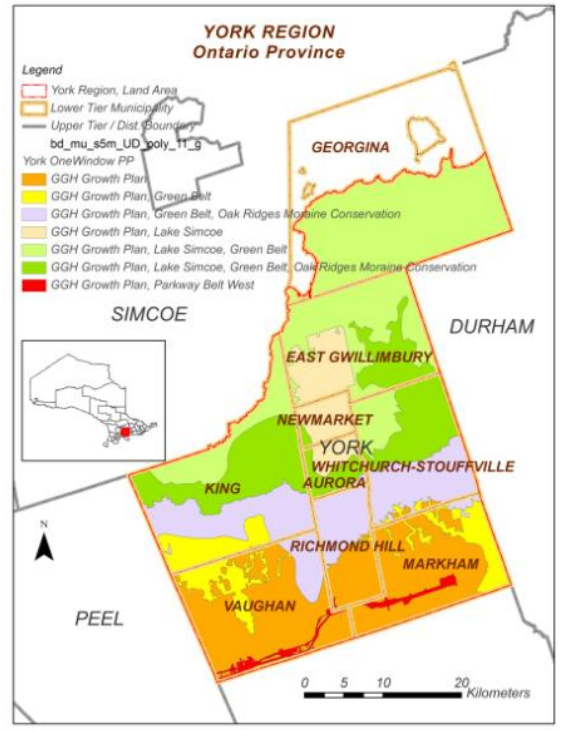

(b)

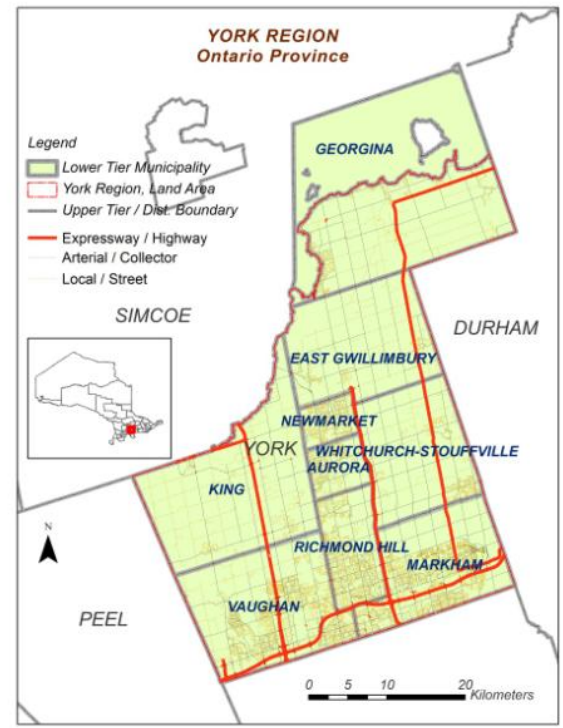

(c)

Figure 2 Ontario Provincial Plans Showing: (a) The Greater Golden Horseshoe Region (See Ministry of Public Infrastructure Renewal), (b) A Portion of Designated Provincial Plans Showing York Regional Municipality, and (c) Municipalities and the Major Transits at York Region (Source: CSC-MAH/MNR, 2010-2011). 
Each municipality should have digital spatial data management properties and protocol with shared entity-sets (Figure 3) to build the georelational data. Data relations are spatially accessible hierarchically (one to many) from the larger geographical area to the smaller municipal revenue jurisdictions, for example, Province $\rightarrow$ Municipal Agency $\rightarrow$ Census Division/Census Tract $\rightarrow$ Dissemination Area. Ten basic entity-sets that are relevant to geo-relational data management are identified to determine variables in the municipal service areas (Table 1). Figure 4 is the information flow diagram showing the implementation of digital spatial data integration and analysis necessary for the municipal affairs in responsible land governance.

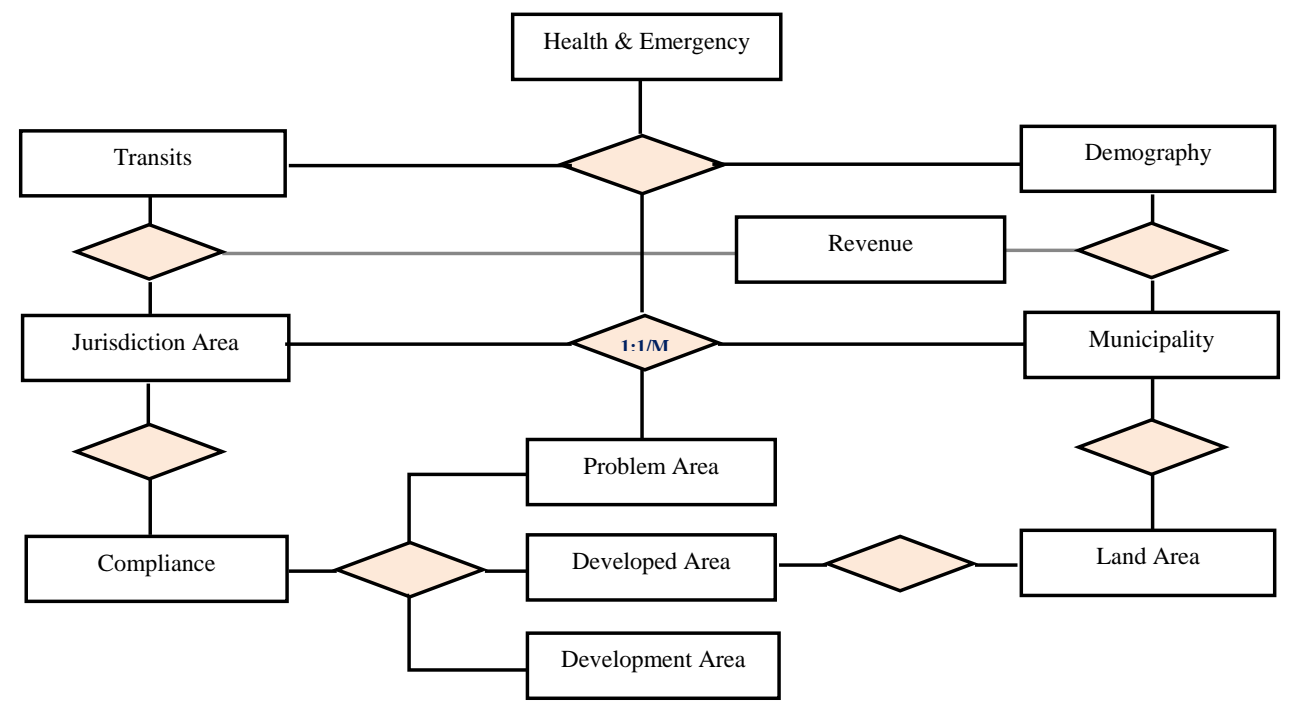

Figure 3 An Entity-Relationship Diagram among the Principal Operators in a Municipality; designated entities and the attributes associated are illustrated in Table 1.

Table 1 Key Entities and Attributes of Digital Spatial Data for a Municipality.

\begin{tabular}{l|l}
\hline Entity & Attributes or Values \\
\hline Municipality & Municipal_Name \\
& MUNID \\
& Status_Single, Lower, and Township) \\
& Region \\
& District \\
& MSO Division \\
& Establishment or New Structure, Year \\
\hline Jurisdiction_Area & Municipal_Name \\
& Land, Ha \\
\hline Demography & Island, Ha \\
\hline Water, Ha \\
\hline & MUNID \\
& Population density, perSq-Km \\
& Dwellings, Number \\
\hline & Households, Number \\
& Population Under 18, Number \\
& Population 19-65 Yrs Aged, Number \\
& Population Above 65 years (seniors) Aged, Number \\
\hline
\end{tabular}




\section{REDRESSING THE MUNICIPAL AFFAIRS WITH 221}

(Table 1 continued)

\begin{tabular}{|c|c|}
\hline Land_Cover & $\begin{array}{l}\text { MUNID } \\
\text { Farmlands or Rural Area, Ha } \\
\text { Urban Area, Ha } \\
\text { Park and Recreation, Ha } \\
\text { Reserve Forest' Ha } \\
\text { Unspecified Area, Ha }\end{array}$ \\
\hline Problem_Area & $\begin{array}{l}\text { MUNID } \\
\text { Landfill, Ha } \\
\text { Brownfields, Ha } \\
\text { Problem Soils, Ha }\end{array}$ \\
\hline Compliance & $\begin{array}{l}\text { MUNID } \\
\text { Area Compliance with OMB, Y/N } \\
\text { Area Compliance with Municipal Acts, Y/N } \\
\text { Area compliance with ZBL, Y/N } \\
\text { Area indicative to } \mathrm{GGH}, \mathrm{Y} / \mathrm{N}\end{array}$ \\
\hline Developed Area (Impervious land) & $\begin{array}{l}\text { MUNID } \\
\text { Community Service Area, Ha } \\
\text { Housing, Ha } \\
\text { Retailers or Business, Ha } \\
\text { Transit, Ha } \\
\text { Park and recreation, Ha } \\
\text { Industry, Ha } \\
\text { Airport, } \mathrm{Ha}\end{array}$ \\
\hline Planned Area (Pervious land) & $\begin{array}{l}\text { MUNID } \\
\text { Community Service Area, Ha } \\
\text { Housing, Ha } \\
\text { Retailers or Business, Ha } \\
\text { Transit, Ha } \\
\text { Park and recreation, } \mathrm{Ha} \\
\text { Industry, Ha } \\
\text { Airport, } \mathrm{Ha}\end{array}$ \\
\hline Health_Emergency & $\begin{array}{l}\text { MUNID } \\
\text { Health Units, Number } \\
\text { Physician, Number } \\
\text { Emergency Service Station, Number }\end{array}$ \\
\hline Transits_Facility & \begin{tabular}{|l} 
MUNID \\
Roads, $\mathrm{Km}$ \\
Highways, Km \\
Subways, Km \\
Rails, Km \\
Transits publicly operational, Km \\
Transits under existing planning, Km \\
Public transports, Number \\
Private vehicles, Number \\
\end{tabular} \\
\hline Revenue & $\begin{array}{l}\text { MUNID } \\
\text { Total Revenue Income, CAD } \\
\text { Per Capita Income, CAD } \\
\text { Annual Budget-Operational, CAD } \\
\text { Annual Budget-Capital, CAD } \\
\text { Annual Expenditure-Operational, CAD } \\
\text { Annual Expenditure-Capital, CAD } \\
\text { Revenue Expenditure, CAD } \\
\text { Federal Allocation, CAD }\end{array}$ \\
\hline
\end{tabular}




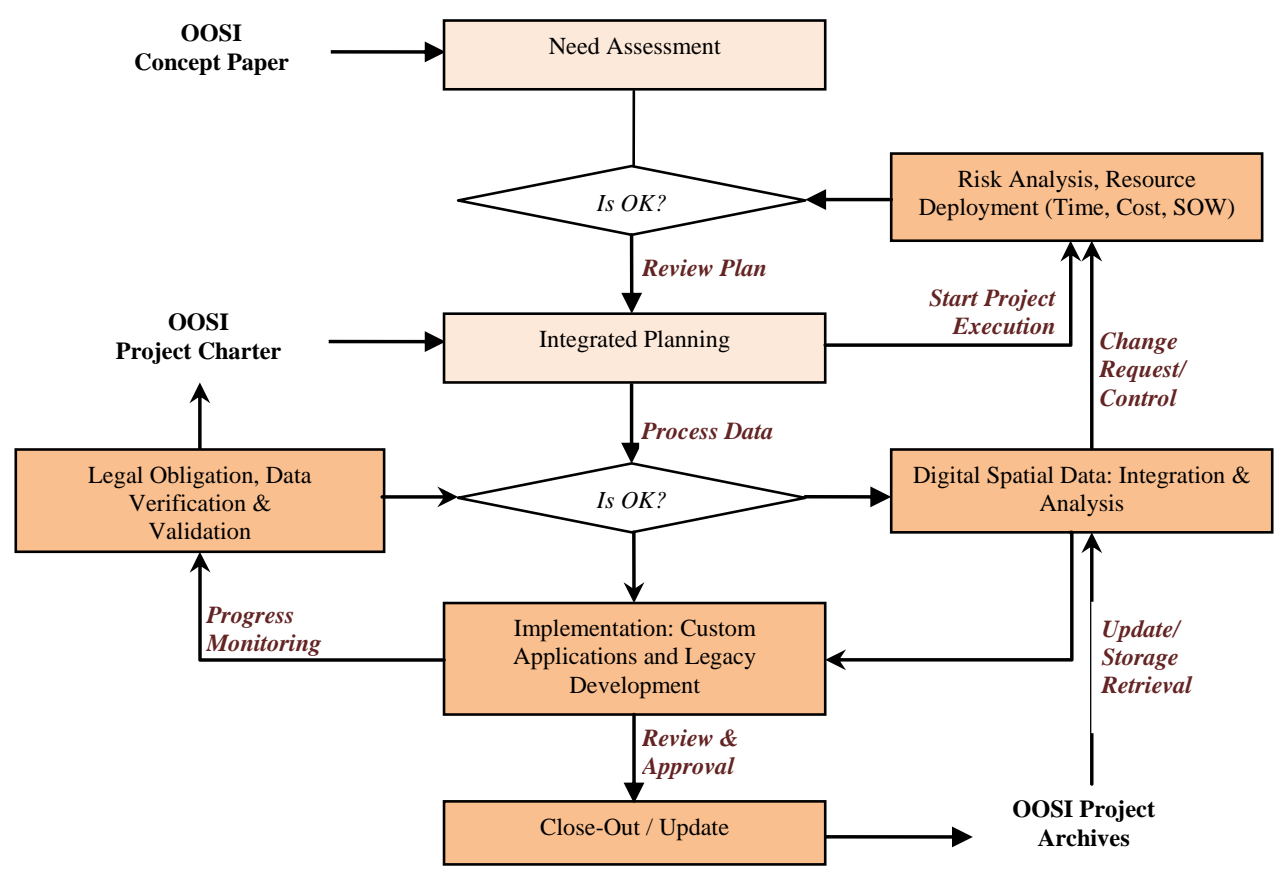

Figure 4 Methodological Schematic of Digital Spatial Data Implementation for Municipal Affairs towards Responsible Land Governance.

This diagram can be useful to extract topographic boundaries such as Census Tracts, Census Division, municipal agency, and the provinces. The administrative or geographical boundaries of all municipal agencies in different tiers (e.g., lower, single, upper) or regional municipalities, districts and counties and provinces should follow the same scale on the ground. For the geo-relational attributes and thematic mapping, the entity-set are described in Figure 3 and Table 1.

\section{Municipal AfFAIRS AND ResPonsible LAND GOVERnANCE}

In the 1980s, the developed countries supported many developing countries to the reform of land administration and cadastral system to delimit the land surveys and registry that includes replacement of large volume of paper records and staff with computer and information technology ${ }^{10}$. This system influences sustainable development in land management in the 1990s and later in the digital databases, definitely the cadastral surveys and spatial data components letting various components

\footnotetext{
${ }^{10}$ IAn Williamson, Stig EnEmark, Jude Wallace \& AbBas RAJABifARD, LAND Adminsitration FOR Sustainable DEVElopment 74—77 (Redlands, CA: ESRI Press 2010).
} 


\section{REDRESSING THE MUNICIPAL AFFAIRS WITH 223}

such as lawyers/surveyors, fiscal, local government, utilities, and land use planning. It also includes the legal means of planning control in neighbourhood plans in land use - where municipalities are responsible for determination of land management and land use policies under the comprehensive municipal plans designated to the local municipalities that should consistently be overseen by the respective provincial government.

Provincial governments in Canada are greatly predictable in regional planning beginning the twentieth Century should appear to be the municipal affairs in responsible land governance. Historically, 1920s idea of "regional planning" rendered to 1960 s "regional economic planning" to 1990 s "city states" towards the competitive global economy with investments in the economically troubled areas to improve infrastructure. Municipal affairs in Ontario, among the ten provinces and three territories in Canada, designate the services to engage the program delivery associated with the local municipal organisation, fiscal and administrative management. It aims to shape the Ontario's strong communities resentment by the implementation of ministries policies and guidelines in governing business such as land use planning, education and training, local government practices, service delivery coordination, and local government structure and operations identification. Transitionally, the provincial governments passed legislations to amalgamate or annexe the municipalities to create larger regional cities reasonably for better service management other than lowering the municipal expenditures.

When a designated rural areas or an adjacent area of a municipality is fetched into amalgamation, the residents demand more urban services ${ }^{11}$ that involve more budget for both the capital expenditures and the operational expenditures. Some examples are Halifax, Toronto, Ottawa-Carleton, and Montreal. These cities have the increasing annual expenses and difficulties in operational and capital cost management in new construction and sustainable municipal services that always pursue the means of land taxation, housing options, infrastructure intensity and intergovernmental relations ${ }^{12} 13$

\footnotetext{
${ }^{11}$ Lydia Miljan \& ZaChary Spicer, Municipal AMALGamation in OnTARio (Fraser Institute May 2015).

${ }^{12}$ Richard M. Bird, Substantial Taxation in Large Emerging Countries: ERIC Plus One, IMFG Papers on Municipal Finance and Governance, Institute on Municipal Finance Governance, No. 6 (2012).

${ }^{13}$ Hong Loan Trinh \& William J. McCluskey, Property Tax Reform in Vietnam: A Work in Progress, IMFG Papers on Municipal Finance and Governance, Institute on Municipal Finance Governance, No. 8 (2012).
} 
14. However, the crucial source of municipal taxes is rather a country's natural resources, agriculture lands, infrastructure, or the properties depending on the geographical majority of population divisible to rural areas and urban composite. A key challenging part of a government in the municipal affairs is to build its "fiscal capacity to support goods and services to its citizens, within its economic, legal and political constraints"15. Many researchers in the field of "municipal finance and governance"16 17 suggested that more tax revenues generation are required from the diverse sources while the major dependency from local property taxes are unavoidable to meet the fiscal capacity for the large cities and the Greater Toronto Area. Moreover, that option is not unlikely the cities in Europe and the USA. Land Value Capture (LVC) and Tax Increment Financing (TIF) ${ }^{18}$ are the possible tools of revenue to funding the new projects as in the transit systems to maintain the municipal services and investments in infrastructure.

By and large, the municipal amalgamation tenders the transition of agriculture and rural lands to the new construction and service areas that simultaneously evolve the migration of agriculture labours to nonagriculture sectors that affects the "relative indicators of agriculture policy development paradigms"19. In particular, the City of Toronto amalgamation case does not signify the reduced level of annual expenditures targeted erstwhile to its amalgamation of four towns in $1998^{20}$. On the other hand, the challenging part of this city is to control the needs for infrastructure development with ongoing transits facilities and new development areas concurrent with the increasing population, mobility and business mass. These issues are indicative to equalise the municipal affairs "to promote the welfare of citizens and sustainable development" if we realise the Local

\footnotetext{
${ }^{14}$ Roy Bahl \& Richard Bird, Decentralisation and Infrastructure in Developing Countries: Reconciling Principles and Practice, IMFG Papers on Municipal Finance and Governance, Institute on Municipal Finance Governance, No. 16 (2013).

${ }^{15}$ ANDREW GrahaM, Canadian Public Sector Financial Management (2007).

${ }^{16}$ Almos Tassonyi, Richard M. Bird \& Enid Slack, Can GTA Municipalities Raise Property Taxes? An Analysis of Tax Competition and Revenue Hills, IMFG Papers on Municipal Finance and Governance, Institute on Municipal Finance Governance, No. 20 (2015).

${ }^{17}$ Harry Kitchen \& Enid Slack, More Tax Sources for Canada's Largest Cities: Why, What, and How? IMFG Papers on Municipal Finance and Governance, Institute on Municipal Finance Governance, No. 27 (2016).

${ }^{18}$ Murtaza Haider \& Liam Donaldson, Can Tax Increment Financing Support Transportation Infrastructure Investment?, IMFG Papers on Municipal Finance and Governance, Institute on Municipal Finance and Governance, No. 25 (2016).

${ }^{19}$ Shamsuddin Ahmed, The Relative Indicators to Agriculture Policy Development Paradigms: Local Restraints, Global Trend, 13(2) Journal of US-China Public AdMINISTRATION 91-121 (2016).

${ }^{20}$ The City of Toronto, Building the New City of Toronto: Three Year Status Report on Amalgamation. January 1998-December 2000 (1998).
} 


\section{REDRESSING THE MUNICIPAL AFFAIRS WITH 225}

Government Act in reference to the "Local Agenda 21",21. However, the rights of individuals, the residents and the community are crucial for both the economic development and the heritage conservation to the responsible land governance.

Municipal affairs should have brought the services in responsible land governance admirably under local control in a geographically defined area. The specific classifications of a local municipal government are cities, towns, villages and municipalities, rural municipalities, and regional and metropolitan municipalities. The powers and responsibilities the municipal governments may exercise are usually set out in a general municipal order which is often known as the Municipal Act, the Local Government Act, or the Cities and Towns Act. The provincial governments determine the powers of municipal government as repatriated in the Canada Constitutional Act $1982^{22}$ while the electorate assesses their performance in regular elections ${ }^{23}$. The concept of municipal annexation or consolidation is a routine restructuring in accounting to boost both the local governments and the public sectors ${ }^{24}$. The jurisdictional scope and regeneration capacity influence the development and implementation within the federal regulations and provincial policy that rather gaps the optimal revenue growth $^{25}$.

The primary sources of municipal revenue are taxes on land tenures, real property and grants from the provincial government. In the perspective of municipal civil services, municipal land appraisals had comprised to five features $^{26}$. They are "land value" (lot size), "effect of depth" (accessibility), "irregular lots" (unequal length), "double frontage" (alley width in feet), and "corner influence". The control of a land subdivision is subject to the approval of the 'plat' before the execution of land record by the respective government authority, for example, a county. Every municipality has a predefined boundary in the document that is known as "Letter Patent", a

\footnotetext{
${ }^{21}$ Niem-Lilati Anita, Finland: Working with LA21 Under Condition of Economic Uncertainty (Chapter 2), in From the Earth Summit To Local Agenda 21: Working Towards Sustainable DeVElopMENT 29 (W. Lafferty \& K. Ekerberg (eds.), UK: Earthscan Publications Limited 1998).

${ }^{22}$ Patrick J. Monahan, Essentials of Canadian Law: Constitutional LaW (3rd Edition, Toronto, ON: Irwin Law, Inc. 2008).

${ }^{23}$ C. Richard Tindal \& Susan N. Tindal, Local Government in Canada (7th Edition, Toronto, Canada: Nelson Education Ltd. 2009).

${ }^{24}$ Statistics Canada. Consolidated Government Revenue and Expenditures, Government of Canada (2008).

${ }^{25}$ G. Ross Stephens \& Nelson Wikstrom, Metropolitan Government and GovernanCe (Oxford: Oxford University Press 2000).

${ }^{26}$ ERnest W. STEEL, Municipal AfFairs 310 - 312, 280 (1St Edition, Scranton, PA: International Textbook Press 1941).
} 
legislative document linked with Canada Gazette ${ }^{27}$. The municipal boundary despite permanent can be changed or reshaped on the state of affairs by improving the description to add or remove properties where only the Cabinet Order can bring the "Letter Patent" into effect and any change in boundary description ${ }^{28}$. Nevertheless, the motivation of the municipal affairs in responsible land governance is subject to at least to three dominant selves. Growth management is a route for municipal affairs (Section II. A), the shared periphery as a dimension of Growth Management (Section II. B), and the approach to integrated land management: relative intuitions of municipal affairs (Section II. C).

\section{A. Growth Management: A Route for Municipal Affairs}

Urban growth management is a route for municipal affairs in responsible land governance that is pertinent to deploy digital spatial data with administrative boundaries consistent with the shared periphery designated by regional plans and environmental conservations. Growth management incorporates the government policy initiatives and is attempted by a municipal agency to diminish the adverse impacts of housing and settlements termed as "urban sprawl" 29 . The demand of the increasing population is always challenging too. The government needs to initiate and ensure available services such as housing, transportation, and employment for the people and the communities by adopting and implementing a set of policy measures and management techniques characterised as "growth management". The state-level growth management arose out of concern because of perverse incentives to maximise the local tax bases development in the municipal government ${ }^{30}$. It esteems the land use within their borders regardless of the external environmental costs and the costs associated with the neighbouring areas. This section illustrates three fundamental notions such as the underlying principles of growth management; the development of growth management; and the growth management implications: policy options.

\footnotetext{
${ }^{27}$ See Transport Canada; www.tc.gc.ca.

${ }^{28}$ The City of Toronto, The Toronto Amalgamation: Looking Back, Moving Ahead. Toronto City Council. Toronto Canada (2000).

${ }^{29}$ Robert Blair, Managing Urban Growth: Can the Policy Tools Approach Improve Effectiveness?, 6(2) Public Works Management Policy (2001), http://pwm.sagepub.com/cgi/content/abstract/6/2/102.

${ }^{30}$ M. Howell-Moroney, Studying the Effects of the Intensity of US State Growth Management Approaches on Land Development Outcome, 44 (2163) URBAN STUDIES (2008).
} 


\section{REDRESSING THE MUNICIPAL AFFAIRS WITH 227}

\section{Underlying Principles of Growth Management}

Sprawl and growth management in the perception of advancement in urban ecology are to communicate human and ecological process on growth management issues. ${ }^{31}$ Counting the fundamental problems in the environmental capital and sustainable development ${ }^{32}$, the principles of growth management can be distinguished with many sorts. Some of them are noticeable unprejudiced as a response to sustainable national income as:

- Changes based on spatial scale and landscape signatures where the structures of growth management emerged from urban landscape signatures varying on spatial scale and temporal changes.

- Constraints of land topography and natural habitats as the real estate agencies encourage the urban growth while biophysical constraints (e.g. topography) and environmental amenities (e.g. natural habitats) influence the decisions regarding land development and infrastructure.

- Higher socio-economic and environmental costs - even though the urban growth has the significant economic, social, and environmental costs-yield the fragment forests, weakens native vegetation, degraded water quality, lower fish populations - that burdens high mobility and an intensive transportation infrastructure.

- $\quad$ Reduced level of land cover in nature appears as a result of urban sprawl, and consequently, the threshold, discontinuity, or amazements are repeatedly unfavourable to the responsible land management.

\section{The Development of Growth Management}

The evolution of growth management illustrates two relative transitions. One is the historical development of growth management, and the other is the modern shape of growth management.

(1) Historical Development of Growth Management. In the 1960s, several states started to experiment with an alternative to the institutional norm of local control over land use ${ }^{33}$. Growth management is a term popularised during the 1970s and 1980s, and that is still widely used today,

\footnotetext{
${ }^{31}$ Marina Alberti, The Urban Ecosystem. Advances in Urban Ecology: Integrating Humans AND ECOlOGICAL PROCESSES IN URBAN ECOSYSTEMS (University of Washington, Seattle, Washington, USA 2008).

${ }^{32}$ Michael P. Todaro, Economic Development (Don Mills, ON: Addison-Wesley 2000).

${ }^{33}$ Arthur C. Nelson, Rolf Pendall, Casey J. Dawkins \& Gerrit Knaap, The Link between Growth Management and Housing Affordability: The Academic Evidence (A Discussion Paper Prepared for the Brookings Institution Center on Urban and Metropolitan Policy, USA 2002).
} 
somewhat interchangeably with smart growth ${ }^{34}$. Growth management technique developed over the past three decades has become a community and social instruments in the toolbox of today's smart growth movement.

The original emphasis of growth management indicates environmental resources preservation by setting limits on new development. In 1969, early examples in the USA included the communities of Ramapo in New York, Petaluma in California and Boulder in Colorado. All three communities experienced rapid growth in the 1960s. A regulation called "adequate public ordinance" was adopted in 1969 to permit new residential development only as public facilities. Due to the imposition of such ordinance, Ramapo (New York) housing constructions were dropped by two-thirds. During the 1970s, adoption of severe growth limits appeared-where Petaluma voted to restrict development to five hundred new units per year, and Boulder limited new housing growth to $1.5 \%$ per annum or nearly about 450 units annually. However, restrictions in both Petaluma and Ramapo survived court challenges. These types of annual limits often implemented through a yearly cap on building permits and being continued in various US communities.

Another example of growth management is the Maryland-launching the implementation of National Capital Park and Planning Commission (MNCPPC) what are now recognised as growth management policies as per back as the 1950s. It illustrates that M-NCPPC oversees planning in Montgomery and Prince George counties in the suburban Washington, DC. A full-fledged growth management strategy became the Montgomery County with conserving open space and new infrastructure investment while directed growth to specific areas within the county. This strategy evolved to preserve countryside by agricultural zoning and transferable development rights that had used to preserve more than forty thousand acres of farmland. However, incentives have been put in place to encourage high-density development around rail transit stations.

It is factual that growth management has evolved into more broadly focused planning and regulatory approach aimed to support and to coordinate the development process. In other words, it has become as a positive framework for directing development in communities rather than as a method for simply restricting growth. Therefore, the primitive consideration of growth management offered importance on three aspects of municipal affairs such as preserving the agricultural land, protecting the environmental conservation, and maximising the municipal tax. Conversely, the latter is contradictory with the previous two notions as the contemporary

\footnotetext{
${ }^{34}$ Oliver Gillham, The Limitless City: A Primer on the Urban Sprawl Debate (Washington, DC: Island Press 2002).
} 


\section{REDRESSING THE MUNICIPAL AFFAIRS WITH 229}

housing options and taxation now and again limit the necessities for heritage and farmlands conservation. Nowadays, the growth management attempts to use planning, policy, and regulatory techniques to influence the allocation of new development across a designated area that increases dependency on spatial digital data to peruse the planning integration with new policy initiative development program.

(2) Modern Shape of Growth Management. The modern shape of growth management is twofold, regional disparity and dynamism, and smart growth as growth management. The issue of "regional disparity and dynamism" in the notions of regional growth and resource mobility stated that regional disparities of development that are attributed to the existing resource endowment, particularly per capita production capacity and stock of the region ${ }^{35}$. It further reveals what is crucial in regional growth is not resource endowment differences in a static situation relatively is the dynamic process of growth.

The dynamism of regional growth is determined by direction, magnitude, and speed of resource movement, mainly capital and labour, within a system of the region. Unrestrained suburban growth causes challenges to the urban housing prices corresponding to the household income. ${ }^{36}$ This trend tersely shows that the "ratio" 37 of the median households' income and the average house prices in the City of Toronto were $1: 4.3,1: 4.4,1: 6.3$, and $1: 10.2$ respectively in $1990,2000,2010$ and 2016. The dynamic process of regional development pattern regarding the process of divergence and convergence of per capita income is illustrated in a simple model which integrates the neo-classical growth theory of factor mobility within the concepts of spatial diffusion of technology and optimum size of the city.

Smart growth as a growth management is a modern shape and a managed growth that attempts to fulfil the need to provide growth for both with economic and in population. At the same time, it limits the undesirable impacts of that growth. The population of the United States is forecast to grow by 45 percent in 2050 where smart growth will help the nation to meet the needs of that expansion without the kinds of negative impacts that have

\footnotetext{
${ }^{35}$ Fu-Chen Lo, The Growth Pole Approach to Regional Development: A Case Study of the Mizushima Industrial Complex, Japan, in Growth Pole StRATEgy and Regional DeVElopment Policy: Asian EXPERIENCES AND Alternative APPROACHES (Fu-Chen Lo \& Kamal Salih (eds.), United Nations Centre for Regional Development, Toronto, ON: Pergamon Press 1978).

36 John SEwEll, The Shape OF THE Suburbs: UndERSTANDING TORONTO's SPRAwl (Toronto, ON: University of Toronto Press 2009).

${ }^{37}$ Calculation is based on public records for the average housing price and the median households' income in the respective years.
} 
accompanied widespread suburbanization ${ }^{38}$. "Smart growth" is defined as a set of interlocking actions grouped into six categories: promoting cities as engines of the economy, controlling urban sprawl, alternative transportation system, agreed on housing choice, protecting natural areas and cultural heritages, and creating community ${ }^{39}$. Besides, "smart growth" would refer to compact, transit accessible, pedestrian-oriented, and mixed-use development pattern ${ }^{40}$. Therefore, growth management now in the form of smart growth is measured by some initiatives and techniques associated with the responsible land governance in municipal affairs can be adapted with two relative inputs such as the policy options consigned from the acts and regulations and the digital spatial data portentous to the physical features (Table 2).

Table 2 Smart Growth Management as a Measure of Responsible Land Governance in Municipal Affairs.

\begin{tabular}{|c|c|c|c|}
\hline $\begin{array}{l}\text { Smart growth } \\
\text { measure/program }\end{array}$ & Techniques and methods & $\begin{array}{l}\text { Policy options: Acts } \\
\text { and regulations }\end{array}$ & $\begin{array}{l}\text { Digital spatial data: } \\
\text { Physical features }\end{array}$ \\
\hline $\begin{array}{l}\text { Open space } \\
\text { conservation }\end{array}$ & $\begin{array}{l}\text { - Regulatory control (e.g., } \\
\text { environmental restrictions, } \\
\text { zoning controls, and transfer of } \\
\text { development rights) } \\
\text { - Easement and deed restrictions } \\
\text { - Tax incentives and Land } \\
\text { Acquisition }\end{array}$ & $\begin{array}{l}\text { - Federal statutes } \\
\text { - Provincial } \\
\text { legislation } \\
\text { - Municipal Acts } \\
\text { - Crown Lands Act } \\
\text { - By-Laws }\end{array}$ & $\begin{array}{l}\text { - Dissemination Area } \\
\text { (revenue jurisdiction) } \\
\text { - Growth Plans } \\
\text { - Municipal } \\
\text { Boundaries } \\
\text { - Lands parcels }\end{array}$ \\
\hline Growth boundaries & $\begin{array}{l}\text { - Local urban growth } \\
\text { boundaries } \\
\text { - Regional urban growth } \\
\text { boundaries }\end{array}$ & $\begin{array}{l}\text { - Local and Regional } \\
\text { Municipalities } \\
\text { - Stakeholders' } \\
\text { participations }\end{array}$ & $\begin{array}{l}\text { - Municipal } \\
\text { boundaries } \\
\text { - Conservation Area } \\
\text { - Transits }\end{array}$ \\
\hline $\begin{array}{l}\text { Compact } \\
\text { developments }\end{array}$ & $\begin{array}{l}\text { - Traditional neighbourhood } \\
\text { developments } \\
\text { - Transit-oriented developments } \\
\text { - Transit villages }\end{array}$ & $\begin{array}{l}\text { - Federal Statues } \\
\text { - Municipal Acts } \\
\text { - Zoning By-Laws }\end{array}$ & $\begin{array}{l}\text { - Local community } \\
\text { areas } \\
\text { - Aboriginal habitats } \\
\text { - Agriculture lands } \\
\text { and transits }\end{array}$ \\
\hline $\begin{array}{l}\text { Revitalization of } \\
\text { older areas }\end{array}$ & $\begin{array}{l}\text { - Downtown and main street } \\
\text { development program } \\
\text { - Brownfield redevelopment } \\
\text { - Grey-field development }\end{array}$ & $\begin{array}{l}\text { - Provincial Policy } \\
\text { - Community } \\
\text { Improvement Plans } \\
\text { - Municipal Acts } \\
\text { - Environmental } \\
\text { Laws }\end{array}$ & $\begin{array}{l}\text { - Planning area } \\
\text { - Recreation and } \\
\text { service centres } \\
\text { - Housing and } \\
\text { occupants } \\
\text { - Heritages }\end{array}$ \\
\hline Public transit & - Local transit programs & - Environmental & - Road network and \\
\hline
\end{tabular}

\footnotetext{
${ }^{38}$ OliVer Gillham, Growth Management and Smart Growth, in The LIMITLESS City: A PRIMER ON THE URBAN SPRAWl Debate (Washington, DC: Island Press 2002).

${ }^{39}$ Canadian Urban Institute, Smart Growth in CANAdA (Toronto, Canada: Canadian Urban Institute 2001).

${ }^{40}$ Wayne Beyea, Christine Geith \& Charles McKeown, Place Making through Participatory Planning, in URban Informatics: The Practice AND Promise Of THE ReAL-Time City (Marcus Foth ed. 2009).
} 


\section{REDRESSING THE MUNICIPAL AFFAIRS WITH 231}

\begin{tabular}{|c|c|c|c|}
\hline $\begin{array}{l}\text { Smart growth } \\
\text { measure/program }\end{array}$ & Techniques and methods & $\begin{array}{l}\text { Policy options: Acts } \\
\text { and regulations }\end{array}$ & $\begin{array}{l}\text { Digital spatial data: } \\
\text { Physical features }\end{array}$ \\
\hline & - Regional transit programs & $\begin{array}{l}\text { Acts } \\
\text { - Transportation } \\
\text { Policy }\end{array}$ & buffer areas \\
\hline $\begin{array}{l}\text { Regional planning } \\
\text { coordination }\end{array}$ & $\begin{array}{l}\text { - Regional Government } \\
\text { - Regional authorities } \\
\text { - Regional infrastructure service } \\
\text { districts } \\
\text { - State planning initiatives }\end{array}$ & $\begin{array}{l}\text { - Growth } \\
\text { Management } \\
\text { Negotiation } \\
\text { - Cross-boundary } \\
\text { policy issues } \\
\text { - Federal Statutes }\end{array}$ & $\begin{array}{l}\text { - Multijurisdictional } \\
\text { municipal boundaries } \\
\text { - Growth } \\
\text { Management Criteria } \\
\text { - Sectoral Attributes }\end{array}$ \\
\hline
\end{tabular}

Source: Adapted from Beyea, Geith \& McKeown (2009).

\section{Growth Management Implications: Policy Options}

Landscape signatures exemplified earlier indicated multi-year land cover classification, "Growth Management Act" ${ }^{41}$ (GMA), and spatial growth management. Landscape metrics comprise urban growth, transportation, housing, natural resources, open space and recreation, and the environment. In urban growth, landscape signatures point three major factors in selecting metrics of benchmarks for urban growth monitoring. The first factor is the standing state of measuring different attributes of the landscape such as landscape composition, intensity, and configuration. The second factor is the choice of classification resolution and spatial scale. The third factor indicates efforts to tie the GMA goals directly to the selected metrics.

The policy options for growth management implication can be observed with three constraints. First, emergence and evaluation of settlement patterns in the spatial and temporal dynamics, urban dispersal causes more dispersal. It causes forest fragmentation that consequently leads to degraded environmental conditions and variations in growth management systems that would allow ecological conditions to recover.

Secondly, identification of challenges of growth management faces complexity, heterogeneity, and amazement situations. It offers a basis for developing an integrated indulgent of the processes and mechanisms that govern urban ecosystem dynamics. At the same time, it offers tools to envisage and assess the effect of future urban growth and to evaluate alternative urban planning and growth-management strategies.

Third, understanding the smart growth policies especially in the North America where environmental problem abetted to understand the

\footnotetext{
${ }^{41}$ In 1990, the Washington Legislature enacted the Growth Management Act (GMA) to guide planning for growth and development in Washington State. GMA requires local governments in fast growing and densely populated counties to develop and adopt comprehensive plans.
} 
development strategy conceivably mainly for three reasons as: to decrease agricultural land encroachment; to reduce the cost of public infrastructure, and to revitalise existing urban areas ${ }^{42}$. The relevance of revitalization of urban areas is strategically formulated to reduce the urban expansion predominantly aimed at the downtown of the cities. It intensifies the use of existing urban spaces that is holding the swelling of population density and business intensity.

\section{B. Land Governance Shared Periphery as the Dimension of Growth Management}

Regional planning relates the growth management with some ideologies and processes where urban growth boundary, regional scale elements, spatial equity (as demographic dispersion), rigorous public process, neighbourhood's model, affordable housing, transit-based development, legislative challenges, and political pressure are crucially reliant. Consequently, public policy in urban sprawl and growth management is an important input for regional planning that preserves responsibility of land governance.

According to the Ontario Ministry of Municipal Affairs and Housing (www.mah.gov.on.ca), restructuring activities are a response to urban growth pressures, changes to corporate responsibilities, and provincial government initiatives. In a debate on municipal consolidation in Canada, the importance of regional planning emerged as an important aspect of discourse where the advocacy for consolidation had been especially evident in regions affected by the rapid physical change ${ }^{43}$. It was especially related to the two case studies based on an urban and rural amalgamation of two municipalities. In overcoming the fragmented local government, the establishment of municipal government was required providing the needs of the citizens. In this regard, the requirements for consolidation may refer to the obligation of following functions as noted ${ }^{44}$ :

The social and economic problems which concern the various municipal divisions of a metropolitan area are largely the same for all. They are the usual problems of urban life, somewhat magnified by the fact that they arise out of

\footnotetext{
${ }^{42}$ Susannah Bunce, The Emergence of "Smart Growth" Intensification in Toronto: Environment and Economy in the New Official Plan, 9(2) LoCAL ENVIRONMENT 177-191 (2004).

${ }^{43}$ Igor Vojnovic, Municipal Consolidation, Regional Planning, and Fiscal Accountability: The Recent Experiences in Two Maritime Provinces, CANAdian Journal of Regional Science, CANADA (2000).

${ }^{44}$ G. Ross Stephens \& Nelson Wikstrom, Metropolitan Government and GovernanCE 36 (Oxford: Oxford University Press 2000).
} 


\section{REDRESSING THE MUNICIPAL AFFAIRS WITH 233}

conditions which exist throughout the entire metropolitan area and not merely in a particular locality. In general, they relate to water supply, sewerage, drainage, construction and maintenance of streets, transportation, fire, police, fire protection, public health, disposal of garbage and other wastes, parks, playgrounds, schools, libraries, hospitals and the like.

Nonetheless, the major challenges or evolutions in planning the municipal affairs ought to be spatially analytic at least in two phases. First, to overcome the defies from the inflation and fiscal crisis, and land use and zoning variances, community populations, business alternatives, and the tool for municipal planning such as master plan preferably with digital spatial data are inevitable. The federal-provincial relations in Canada ${ }^{45}$ to the municipal affairs in fiscal perspective determine the constraints especially in planning the individual municipal budget ${ }^{46}$. Second is to identify the contiguity and connectivity among the suburbs, transits, housing and settlements, including schools, parks, retailers, parking lots, public health, and emergency service areas - those are incremental with the cost indices of a municipality.

Consequently, growth management needs environmental negotiation and mediation among the municipal proponents to reach an agreement to protect the demolition of environmentally conservation and heritage areas, which are elite by the multi-storied developers and the urban planners, are imaginable for the safe bet of economic growth. However, the meaning of interpretation of sustainable development is to put the environment first in consideration, including the transit-friendly land use planning with HighDensity Transit Centre connecting the urban core, urban fringe and the suburbs $^{47}$. It concluded two challenges.

First is the newly developing areas would need integration of transitfriendly policies and designs while many suburban municipalities have a little or rare transit requirement corresponding to their population and business, and urban density. Second is to uplifting existing developed areas during development planning for better transit support. In such case, the importance of extensive digital spatial data is inevitable to identify and planning the determinants needed for sustainable municipal affairs to the

\footnotetext{
${ }^{45}$ Robert Young \& Christain Leuprecht (eds.), Canada: The State of Federation 2004. Municipal-Federal-Provincial Relations in CANADA (Montreal, QC: McGill-Queen's University Press 2004).

${ }^{46}$ Melville L. McMillan, Municipal Relations with the Federal and Provincial Governments: A Fiscal Perspective. Municipal-Provincial-Federal Relations Conference (May 9-10, 2003 unpublished manuscript), http://www.queensu.ca/iigr/sites/webpublish.queensu.ca.iigrwww/files/files/conf/ Arch/03/03-2/McMillan.pdf.

${ }^{47}$ W. L. McEachern, Transit-Friendly Land Use Planning: A Key Ingredient Supporting Urban Environmental Quality and Economic Development, 31(5) Plan CANADA 15-17 (1991).
} 
targeted "community service" areas allied to the responsible land governance.

In North America, urban growth boundary (UGB) is an important idea to preserve and protect the land by developing greenbelt. In the Greater Toronto Area and Hamilton (GTAH), Greenbelt is much efficient and indicative of sustainable development. In fact, greenbelt concepts are also successive in many cities and countries in Asia and Europe. For instance, Coastal Greenbelt in Bangladesh which despite had a partial implication in protecting coastal lands resources was a greater initiative in government policy in the 1980s. In Canada, Ontario Greenbelt has a tremendous impact to protect the forests and natural resources in the designated area, and the southern Ontario that is separated geographically from the harshness of winter storms than the northern Ontario. We can stipulate this issue at least with four key aspects: the growth boundaries as regional versus local management, regional growth and resource mobility, the community planning process in growth management, and redressing needs for the municipal affairs.

\section{Growth Boundaries: Regional versus Local Management}

In restricting the outward expansion of growth and preservation of the specific land, "urban growth boundaries" 48 (UGBs) are gritty by creating a Greenbelt around the area to protect other land adjoining to the area. In this situation, growth is encouraged in the boundary and discourages outside the boundary. The housing development options in land use by "sprawl" was first uttered by Earle Draper in 1937. It had experienced with "leapfrog" dispensing low-density residential and huge undeveloped space triggered fiscal disparity among the localities and failed to provide effective open space ${ }^{49}$. UGBs were more efficient by covering more than a single municipality. Thus growth boundaries are important factors for preserving a particular area with functional open space, agriculture, forests, and other lands designated and controlled under the Zoning Bylaw. "Urban Growth

\footnotetext{
${ }^{48}$ Is useful tool to identify a geographic location within which a municipality attempts to cluster development in the designated service areas that typically attempt to limit sprawl and preserve agricultural or rural areas around and urban core; for more information see: http://www.sustainablecitiesinstitute.org/topics/land-use-and-planning/smart-growth/urban-growthboundaries.

${ }^{49}$ Susan Handy, Robert Paterson, Jumin Song, Jayanthi Rajamani, Juchul Jung, Chandra Bhat \& Kara Kockelman, Techniques for Mitigating Urban Sprawl: Goals, Characteristics, and Suitability Factors (Research Report 4420-1. Austin: The University of Texas 2002).
} 


\section{REDRESSING THE MUNICIPAL AFFAIRS WITH 235}

Boundaries Act ${ }^{\prime 50}$ denoted an incentive to property owners to preserve land outside the border of open space and to develop land within the boundary for urban purposes.

Communities broadly think to achieve real changes in regionally rather than locally. While sprawl is a regional phenomenon and some of the issues raised by sprawl are most critical at the regional level relates growth boundaries, transportation, land and general distribution of fiscal resources ${ }^{51}$. All of these factors may affect multiple communities across a given metropolitan area although municipalities have roads, transits, and transportation system. The tendency for sprawl development as the land records to effects of simply leapfrog into the community service area can severely weaken the effect of undertakings such as placing the local boundary in a municipality.

\section{Regional Growth and Resource Mobility}

The dynamism of regional growth is determined by direction, magnitude, and speed of resource movement, mainly capital and labour, within a system of the region. The dynamic process of regional development pattern regarding the process of divergence and convergence of per capita income represented in a simple model integrates the neo-classical growth theory of factor mobility ${ }^{52}$ within the concepts of spatial diffusion of technology and optimum size of the city.

\section{The Community Planning Process in Growth Management}

The community planning process varies globally depending on legal frameworks, local traditions, and priorities. Participatory planning is necessary tools for achieving success while four critical elements are: (1) a common goal; (2) involved stakeholders with the desire to work towards the goals; (3) general democratised information to inform the process; and (4) a means of productive engagement. Participatory planning requires mutual understanding (community consensus) among citizens, planning officials,

\footnotetext{
${ }^{50}$ Peeter Pollock, Urban Growth Management Strategies. Sustainable Community Development Code (Research Monologue Series. Urban Form, Transportation. The Rocky Mountain Land Use Institute 2008).

${ }^{51}$ Oliver Gillham, Growth Management and Smart Growth, in The Limitless City: A Primer ON THE URBAN SPRAWl DeBATE (Washington, DC: Island Press 2002).

${ }^{52}$ Fu-Chen Lo, The Growth Pole Approach to Regional Development: A Case Study of the Mizushima Industrial Complex, Japan, in Growth Pole StRategy and Regional Development Policy: Asian EXPERIENCES AND ALTERNATIVE APPROACHES. United Nations Centre for Regional Development (FuChen Lo \& Kamal Salih, Kamal (eds.), Toronto, ON: Pergamon Press 1978).
} 
developers and government policy-makers. A similar argument is that a participatory approach in community planning is also termed as Participatory Action Plan Development (PAPD) to involve the systematic efforts and to visualise community-desired future action plan with the competencies and inputs of all stakeholders in the process. Thus community involvement in the planning process is a critical input for policy decision in growth management as a functional effectiveness of responsible land governance.

\section{Redressing Needs for the Municipal Affairs}

Improvement of available services for housing, transportation, and employment in a municipality is noticeable to the responsible land governance. Implementation of a sustainable growth management is the concept of Smart Growth has become an ideal process to reduce horizontal expansion of urban-regional growth. Besides, the process is to improve the uses of land by more development of building infrastructures and intensity of housing by population and working peoples in the core areas of the city. Municipal planning remains by abiding or improving the public policy or governmental actions.

In turn, the essential is to revisiting the zoning permits, Provincial Policy Statement, or the Planning Acts where applicable. First, examination of spatial indicators in economic perspective mainly for four factors: population, housing, transport, and employment. This review will consider different published materials such as Statistics Canada, and the City of Toronto for analysis and interpretation of long-term change (e.g. 19862016). Second, development of spatial data and resource inventory analysis in combination with basic geographical features is necessary. In this case, digital spatial data are community boundaries, land use cover, and transits to assess location-specific changes over the period for a particular municipal dissemination area. Identification of problems from change analysis and evaluation of relevant policy options for growth management implementation are required to justify the changes in local-scale over a regional-scale. Third, use of Geographic Information System ${ }^{53}$ (GIS) provides substantial input in public policy decision in growth management. Public involvement in planning deploys GIS system where the federal

\footnotetext{
${ }^{53}$ See: (a) GetTing Started with Geographic InFormation Systems (Fifth Edition, Keith C. Clarke ed., 2011); (b) GEOGRAPHIC Information ANALYSIS (Second Edition, by David O' Sullivan \& David J. Unwin, 2010); and (c) UNDERSTANDING GIS: AN ARCGIS PROJECT WORKBOOK (for ArcGIS 10, by Christain Harder, Tim Ormsby \& Thomas Balstrom, Redlands, CA: ESRI Press).
} 


\section{REDRESSING THE MUNICIPAL AFFAIRS WITH 237}

government, the provincial government, and municipal government in Canada are the examples that need massive development of digital spatial data to mapping the local municipal attributes by avoiding the dangle features in a cleaned topology. A real argument of urban geo-data is that urban growth management has importance on information pyramid within the hierarchy of data $\rightarrow$ information $\rightarrow$ knowledge $\rightarrow$ requirement $\rightarrow$ good decision-making. In a GIS-based computational information management ${ }^{54}$, location-specific digital metadata is linked with satellite images classifications and Global Positioning System (GPS) data especially for ground verification, data interpretation, and information management as a whole. Spatiotemporal (spatial and temporal) growth is determined and measured by using GIS technology including appropriate software, satellite imagery, and GPS data. A further opinion is that the study involves a comprehensive input from the existing literature and relevant perceptions on urban sprawl and growth management issues where policy intervention is necessary with social, environmental, and economic considerations.

\section{Approach to Integrated Land Management: Relative Intuitions of Municipal Affairs}

Unsurprisingly, the array of planning approaches is in the policy options among the three major proponents of a town such as the developers' approach, the citizens' committee approach and the municipal planners' approach. The planning solutions encounter between the economic growth value assessed by the transportation planners and the heritage conservation value perceived by the environmental planners in the complexity of the approaches disclosed ${ }^{55}$ :

A transportation planner evaluating the work of an environmental planner may well find fault with the assumptions made, methods used, or decision taken; similarly, the environmental planner might criticise the choices made by the transportation planners. Choice reflects the values and interest base from which the planner operates.

The common environmental policy in road transportation constitutes the determinants in urban areas precious by greenhouse gas emissions and

\footnotetext{
${ }^{54}$ For example, Shamsuddin Ahmed, Land Zoning Information Management (Chapter 9), in Inception Report: Study of Detailed Coastal Land Zoning Including Two Pilot Districts of Plain Land Project, Ministry of Land, Government of the People's Republic of Bangladesh 153-169 (November 2007).

${ }^{55}$ Jill Grant, Planning Canadian Communities, in A Reader IN CANADIAN Planning: Linking Theory AND PRACTICE 13 (Jill Grant ed., Toronto, ON: Nelson, Thomson Canada Limited 2008).
} 
carbon lands nexus ${ }^{56}$. The Greater Toronto and Hamilton Area (GTHA) transportation in Ontario measured two major impediments ${ }^{57}$. First, a loose network in rapid transits to and from Downtown Toronto succeeds as a result of old infrastructures built several decades ago. Second, there had been a faster increasing rate of private automobile trips $(56 \%)$ than that of the population (45\%) between 1986 and 2006. Both situations are not a substantive mechanism to the responsible land governance. However, the mature municipal agencies or the highly populated cities look for new highdensity residential areas and multi-storied buildings to generate more revenue perhaps for sustainable service management is defying or amending the Zoning Bylaw and the Municipal Acts regardless to the environmental and social views.

The leading cities are facing the challenges to overcome public opinions in divergence with the real estate developers and the municipal authorities. Government policies and public decisions confront the existing Zoning Bylaw and the citizens' opinions for a new Zoning Ordinance that fairly turns into "public notice" by dint of the Municipal Acts. Sometimes, in such case, land considered to be amalgamated is subject to the proposed Minister's Zoning Order Revocation. This section illustrates the intuitions notable from perspective to reality applicability with the municipal affairs in land governance. There are at least four participatory instances as based on factual observation in 2008-2009: (a) Municipal Policy Compliance: variance in private dwellings; (b) Municipal Avenue Corridor and Neighbourhood revitalization; (c) Local Government in Action: planning implementation process; and (d) Municipal Affairs Connected Resources: environmental conservation centre.

\section{Municipal Policy Compliance: Variance in Private Dwellings}

In the context of land tenures and property holdings, the Planning Act of Ontario grants authority to the designated "Committee of Adjustment" to make decisions on one or more of the adjustments or variances as ${ }^{58}$ :

- "Minor variances" from the Zoning Bylaw;

- Permission to alter or change a lawful non-conforming use of land;

- Consent (approval) to severe land divided that is a parcel of land into

\footnotetext{
${ }^{56}$ Shamsuddin Ahmed, Environmental Policy for Road Transportation: Greenhouse Gas Emissions and Carbon Lands Nexus, 12(5) Journal OF US-China Public AdMinistration 378 - 401 (2015).

${ }^{57}$ Metrolinx, The Big Move: Transforming Transportation in the Greater Toronto and Hamilton Area. Greater Toronto Transportation Authority (November 2008).

${ }^{58}$ The City of Toronto, Committee of Adjustment-Applications (1998-2016), http://www.toronto.ca/311/knowledgebase/92/101000044392.html.
} 


\section{REDRESSING THE MUNICIPAL AFFAIRS WITH 239}

more than one lot;

- Consent to register a mortgage over part of property;

- Consent to register a lease over part of a lot for more than 21 years;

- Validation of land title when there has been an error in the description of the land.

Observation denoted that the objective of the meeting of the "Committee of Adjustment" was mainly two. The former is to ensure the confirmation of the declaration of interest under a local conflict of interest act of the deputation items of variance applications made by the residents and house-owners in the respective jurisdiction. Consequently, the latter is to carefully ensure that the intent and purpose of both the Zoning By-law and the Official Plan are sustained during the decision made by the committee for such a minor variance.

The participants in the committee of adjustment meeting were the committee panel and the residents who made the applications for variance of their building or houses. The meeting appeared with critical decisions on individual cases of the "deputation" items (for instance, from \#7 to \#10), of which, some of the variance applications were:

- $\quad$ Setting a privacy screen of the house kitchen (approved).

- The addition of one bathroom on the second story of a house (approved without any condition).

- Reconstruction of existing damage with at the side yard where the application was endorsed with some condition, such as landscape provision, as there is no specification in Provincial Policy Statement and Planning Act regarding this issue as one of the committee members opined. The committee suggests for a further review of the application with relevant documents.

- Reconstruction of a deck at the back and to the north side of the building (approved by the committee unconditionally).

Therefore, the essential aspect of each decision preceded with the hearings from the several residents was that every member of the committee would have agreed over each case of variance applications with the policy compliance before the decision of the approval agreed by the chair of the committee. The municipal affairs in housing options and taxation businesses have options for digital spatial data categorise the frequencies of minor variances in land parcels or house properties by municipal dissemination area.

2. Municipal Avenue Corridor and Neighbourhood Revitalization

The development stratagem of a municipal Avenue corridor applies to 
the need of business improvement and community services. In a policy context, the elaboration of an area is completely reliant with the Official Plan of a designated city. They are infrastructure, proximity to public transit, proximity to jobs, and community services. As well, contemplation of another issue such as "Places to Grow" that is growth should be directed to existing urban areas.

For example, Parkdale Avenue Corridor in the city of Toronto aimed to move toward an integrated planning approach suitable for an elusive social ecosystem complying the existing policy, legislation, and regulations to support mixed-use and diverse character of the neighbourhood. Since the 1800 s, the common characteristics of Parkdale developed with many important deliberations such as a vibrant commercial corridor, the multicultural destination of a various community, and architecturally significant establishments including the social and cultural heritages.

Interestingly, distribution of dwelling population by age group reveals a major change in the designated area. For example, from 2001 to 2006, the population had been decreased nearly in all ages, including infant $(-15.2 \%)$, youth ages $25 \sim 34(-16.5 \%)$, and the seniors $(-9.9 \%)$ except the age-groups 45 54 and 55 64 that had increased respectively $21.4 \%$ and $4.4 \%$. One reasonable argument behind this changing phenomenon was that the avenue adjoining neighbourhood had a lack of standard quality of housing and social services. The proportion of tenants or rented households was $71.3 \%$ out of 24,130 dwellings. The percentage of households was much higher than average numbers of tenants in the city $(45.6 \%)$ while $36.8 \%$ of total population noted were visible minorities in the Parkdale neighbourhood.

In 2009, a sensible consultation plan for community development ascertained the key components for business and local economic development with the public realm, heritage, housing and business service, and mobility. Nonetheless, the key impediments were housing facilities for the occupants. Most of the houses remain old by the structure and subsequently demonstrated a lack of standard dwelling rooms. City services for utilities like water and sewerage were necessary to improve the area potentially with streetscape beautification, new store opening, capital design strategy, and project piloting for legalising the residential houses. The challenges remain in developing the implementation plan with the construction of the Gardiner Expressway (on urban transportation issue), deinstitutionalization of CAMH patients (concerning health and emergency), a high number of rooming houses \& bachelorettes, and afflicted by drugs addiction and undesired business. 


\section{REDRESSING THE MUNICIPAL AFFAIRS WITH 241}

\section{Local Government in Action: Planning Implementation Process}

In 2008, learning from the "Toronto Water 2009-2018 Capital Program Development" meeting observation denoted that the challenges for a municipal agency in line with the provincial government policy were the consumers' demand with the optimal cost of water supply and wastewater management services. The backlog in Toronto Water issue was higher than any other major Canadian urban centre rather because of the fragmentary infrastructure and housing concurrent with the increasing number of residents. Growth projects provided additional water supply and wastewater treatment capacity to the sustainable service management for a projected population of three million people in the City of Toronto by 2031. The goals were predominantly three. First, improving the water efficiency with high water quality ensuring public health, safety and the environment that includes unidirectional water main flushing, closed circuit television inspection of municipal sewers, storm-water quality investigation, sewage flow monitoring, infiltration inflow program, no-dig sewer rehabilitation project, water main rehabilitation program ${ }^{59}$.

Secondly, to reduce water losses in the distribution systems of 5,850 $\mathrm{km}$ water mains average long 55 years, with about $17 \%$ over 80 years of age and $6.5 \%$ over 100 years old ${ }^{60}$. Thirdly, the expansion projects by six service sections such as water treatment and supply, wastewater treatment, district operations, water infrastructure management, operational support and business unit support. The expansion projects are required to maintain all these systems for ensuring long-term water planning in Toronto ${ }^{61}$.

Besides, there are other impediments in allocating and implementing the budget line of the Toronto Water 2008 which permitted a Capital Budget of $\$ 410.00$ million was $18.8 \%$ or $\$ 76.982$ million spent, as at June 30th, 2008. The capital budget outlay rate was affected by the huge snowfall in early 2008 which imperfect structure of work from January to April and delays in obtaining environmental assessment approvals from the Ministry of the Environment.

Perhaps, for a municipal agency, it is infrequent to having the structured consultations especially with the participation of the stakeholders. The underlying components of the issue were that the Council approved the 2009s Capital Budget for Toronto Water that includes a total project cost of

\footnotetext{
${ }^{59}$ The City of Toronto, Toronto Water (2009), http://www.toronto.ca/water/improvements/index.htm.

${ }^{60}$ The City of Toronto, Toronto's Water Supply System, http://www.toronto.ca/water/supply/system/ watermains.htm (2009).

${ }^{61}$ The City of Toronto, Toronto Water at a Glance, http://www.toronto.ca/water/glance.htm (2009).
} 
$\$ 1.567$ billion, and 2009 cash flow of $\$ 488.438$ million plus future year commitments of $\$ 2.224$ billion. It comprised the provisions of new Cash Flow funding for the 242 new sub-projects with a 2009 total project cost of $\$ 1.567$ billion that required cash flow of $\$ 14.120$ million at the end of the flow in 2017. However, Toronto Water had a significant infrastructure rehabilitation backlog on the city's population and business at the current state.

A thorough analysis was taken by the city to update estimates of Toronto Water's water and wastewater infrastructure restitution of backlog. The whole build-up has been estimated to be $\$ 1.8$ billion: $\$ 1.3$ billion in sewer and water main infrastructure and $\$ 0.55$ billion for water and wastewater treatment plants and facilities. The underlying analytical indicator was to update estimates of Toronto Water's water and wastewater infrastructure renewal backlog which indeed need optimal digital spatial data to determining the service split at the dissemination area level. In relations to municipal finance and governance, the analysis showed that an average investment estimated at $\$ 253$ million per year was required for the next decade to prevent any further growth in the infrastructure renewal backlog.

4. Municipal Affairs Connected Resources: Environmental Conservation Centre

Kortright Centre for Conservation (KRC) is a leading environmental and renewable energy education and demonstration centre in Ontario. It covers an area of 325 hectares of pristine woodlands among the other natural resources. This conservation centre aimed to adequately implement the regional growth, including the transits, housing, forests and agriculture.

Regional development encompasses extensive transportation network; several major highways transect the municipality of Vaughn (in Ontario) where the conservation centre is. The area provides easy access to highway systems, including Canada's first electronic Toll Highway 407 in 1998 in the Greater Toronto Area (GTA). Forests vegetation shields its scenic lookout along the traverses. However, the relevant indicator of its growth is residential and housing development in adjoining area. The special feature of this residential area is unique which have a diversity of housing types and density including some bare land, and the area under mixed land use and commercial operations. The extent and growth of the urban area, from the observation point of view, includes a collected of a range of land uses including prime farmland, open space, aggregate extraction zones, 


\section{REDRESSING THE MUNICIPAL AFFAIRS WITH 243}

settlements and housing, and environmentally sensitive areas.

The association of private and public organisations are dedicated to the protection of the natural environment and the promotion of sustainable resource use including energy and housing development. Three types of development partners brought the growth efforts. They are namely: (a) Onsite Partners led by the Toronto and Region Conservation Authority (TRCA) for development of renewable energy in Ontario, (b) Local Partners, dominantly the Environment Canada, and (c) the Sustainable House Partners include CMHC (national housing agency in Canada), Enbridge, Region of Peel, Hydro One and other from the private sector.

The change dynamics for future is a continuing process to enrich existing sustainable community initiatives and support the growth of environmentally friendly urban development. In connection with this, goals of the sustainable management system (SMS) include Eco-Offices for Ontario Eco-Schools Program, energy management system that operates over 100 buildings although many of which are to be moderated with efficient conditions. The development stage involves the construction of houses with semi-detached and mixed community covering heating system, water system and air conditioning system solar and mini-boiler coverage. As a matter of facts, the area provides the economic and an optimal benefit to the community and people.

\section{Digital Spatial Data: Management Protocols and Properties}

The radical views illustrated in the previous section indicate the necessity of organised digital spatial data in municipal government business. Municipal Affairs in Ontario are multifunctional with the community services ought to be allied with the land resources in optimal municipal operations and identification of restructuring and the municipal services with good governance. It obligates the measurable or objectively verifiable indicators corresponding to the objectives, methods and inputs of the local municipal services applicable to operations management which indeed need digital spatial data. Good governance in Canadian authorities is assembled which has to be operative to the high-quality of decision-making ${ }^{62}$ and accountability in policy implementation at the local governance.

Cities, data, and digital innovation have the application on the availability of large-scale digital datasets that run the opportunities in delivering the city services. In this case, the City of Toronto in Ontario has

\footnotetext{
${ }^{62}$ Zack Taylor, Good Governance at the Local Level: Meaning and Measurement. IMFG Papers on Municipal Finance and Governance, Institute on Municipal Finance Governance, No. 26 (2016).
} 
advancement in digital innovation efforts to harness data however, is behind the City of London in England in promoting Open Data ${ }^{63}$. Open Data is rather intensive to the electronic records and documentary materials with technological interventions pertinent to ease the local municipal affairs such as community services in utilities, transportation, health and emergency, education and culture, and environmental management. Canadian provinces and cities are equipped with digital spatial data. The Ministry of the Natural Resources and Forestry (MNRF) is responsible for Ontario Land Management such as the Crown Land and the Land Information Ontario (LIO), including municipal boundaries, soils type, road network, wetlands, provincial parks, and survey and registry. Processing and analysis of digital spatial data, in other words, operational geographic information system (GIS) is twofold: vector format in linear features (e.g., line, boundary and point), and raster format in pixel resolutions (that is sourced from satellite imagery or converted from vector data). Both data format are tremendously applicable to the government business in municipal affairs to the various community services.

The responsible land governance is to contour: first, identification of the key attributes and entity sets; second, structuring of the geo-relational database connecting the activities and services at the Dissemination Area; and finally, the thematic features of each municipality and their contiguity. On the contrary, responsible land governance is obviously substance at least to the three central obligations such as approach in integrated land management, shared periphery negotiation for economic and environmental growth moratoria, and digital data automation properties and protocols.

The issues of the land resources and the community services are many where policy planning is necessary for the sustainability of government business in municipal affairs. Some of the necessities on a priority basis are perusable as:

- Recognising the local resources and stakeholders;

- Determining the critical components of potential risk;

- Develop location-specific environmental and land use information;

- Vulnerability analysis and hazard mapping;

- Review of local land use policy to identify gaps and opportunity;

- Implementation of land resources data connecting the "dissemination areas".

The major limitation in synchronising digital spatial and temporal data often bound the common risk indicators among the other issues in public

\footnotetext{
${ }^{63}$ Mark Kleinman, Cities, Data, and Digital Innovation. IMFG Papers on Municipal Finance and Governance, Institute on Municipal Finance Governance, No. 24 (2016).
} 


\section{REDRESSING THE MUNICIPAL AFFAIRS WITH 245}

service. Spatial data management perchance deviates time, cost, and scope of work including staffing (Table 3). The risk factors are technical, financial, political, legal, service and human resources that are relevant to manage the successful execution and close-out of data governance project deemed to be planned with integrated management approach. In municipal business perspectives, the economic growth moratoria appear as a result of a failure in planning ${ }^{64}$ or to decline or control the development activities for the legislatively-enacted period. In such case, two recent examples are prominent in Ontario. One is the Bill 73, the Smart Growth for Our Communities Act, $2015^{65}$. The other example is a plausible step by the Government of Ontario directing a two-year moratorium on water bottling operations to protect the groundwater conservation with an option for groundwater research and management as debated by public opinion in 2016 .

Table 3 Potential Risk Indicators in Digital Spatial Data Management Protocols.

\begin{tabular}{l|c|c|c|c|c|c}
\hline \multirow{2}{*}{$\begin{array}{l}\text { Risk Category: } \\
\text { Factors }\end{array}$} & Events or Causes & \multicolumn{2}{|c|}{ Risk } & \multirow{2}{*}{ Risk Mgt. } \\
\end{tabular}

Note: $\mathrm{H} \rightarrow$ High, $\mathrm{M} \rightarrow$ Medium, $\mathrm{L} \rightarrow$ Low; ADM/DM $\rightarrow$ Assistant Deputy Minister / Deputy Minister; $\mathrm{PM} \rightarrow$ Project Manager

Land governance intuitionally is the systematic approach where implementation of digital spatial data is cohesive to the Ontario municipal service requirement seems to be an affliction to Ontario provincial cluster ministries. The land resources and the community services should be

\footnotetext{
${ }^{64}$ Antonio M. Bento, The Effects of Moratoria on Residential Development: Evidence from Harford, Howard, and Montgomery Counties, National Center for Smart Growth University of Maryland (February 2006), http://smartgrowth.umd.edu/assets/bento_2006.pdf.

${ }^{65}$ Borden Ladner Gervais LLP, Bill 73, The Smart Growth for Our Communities Act 2015 (March 24, 2015), http://blg.com/en/News-And-Publications/Documents/Publication_4342_1033.pdf.
} 
manifest at least to four measurable understandings. (1) The metadata and the corporate business operations. (2) Data identification and mapping with entity-relationship data model with a basic entity-set and attributes for a municipal agency, and metadata integration and analysis methodology. (3) A detailed implementation plan. (4) Digital spatial data management principal. Entity Relationship (E-R) Data model represents the logical framework of database architecture to determine the associations among the linked attributes and their entities thus provide relational database structure. E-R model shows the relationships "one-to-one" or "one-to-many" among the entities as single Municipality. In the case of Ontario Province, the relationship is "many-to-many" except for the two entities "Municipality" and "Jurisdiction Area" with the corresponding attributes.

The semantic of digital spatial data (or geographic information system) is a database that is constructed from users' perspective by "data definition language" (DDL) and maintained by "data manipulation language" (DML) being operated by "structured query language" (SQL). Spatial Database follows the relational attributes to describe and shape the pattern of thematic maps through the geo-relational data structure. The output of data model tends to determine municipal-wise relational dataset and analytical attributes widely in a population and business context preferably to municipal Dissemination Area.

For example, these attributes can be the average household income, average housing price, the number of low-income families, school-aged population, and work-aged population, the number of elderly or senior population, the number of single women family, and the number of dwelling units by category. The socioeconomic and demographic indicators by various thematic maps are unavoidable in the current trends of the provincial planning needs and the new policy initiatives. The basic outputs from the designated attributes or variables are supportive to prioritising the specific municipal agencies in public asset management or new infrastructure development such as for housing (while critical examples are seniors and single women family), schools, daycare centre, and healthcare, and the service areas associated with taxation.

This portion of the paper synthesises a detailed outline with emphasis on appropriate municipal business data identification and mapping with entity-relationship data model with a basic entity-set and attributes (Figure 3 ), and metadata integration and analysis methodology (Figure 4). Digital Spatial Data governance requires both institutional and technical effectiveness mostly with shared infrastructure in optimal data processing, e.g., satellite imagery and geodata especially after the Land Registry and 


\section{REDRESSING THE MUNICIPAL AFFAIRS WITH 247}

Cadastral survey (Table 4). On the whole, the functional use of digital spatial data is necessary to readdress the municipal affairs in overcoming the challenges in the following basic operational areas that apparently in connection succeeds the other businesses of a municipality.

Table 4 Typical Supports for Digital Spatial Data Implementation.

\begin{tabular}{l|l}
\hline Requirement & Theme and Factors \\
\hline Organizational Support & $\begin{array}{l}\text { Designated Geographical Area: } \\
\text { location, scale, accessibility, and data referencing }\end{array}$ \\
\cline { 2 - 2 } & $\begin{array}{l}\text { Planning and Implementation Issues: } \\
\text { human resoucres, Network Infrastructure, GIS Database, and Integrated plan } \\
\text { (local/departmental, ministerial, and intergovernmental). }\end{array}$ \\
\hline Technical Support & $\begin{array}{l}\text { Systems Configuration: } \\
\text { hardware, software, data architecture, and database design (e.g E-R Model, Data } \\
\text { Model) }\end{array}$ \\
\cline { 2 - 2 } & $\begin{array}{l}\text { Data Management Issues: } \\
\text { Data Coordination (standard/accuracy, partnership, stewardship), Data Development, } \\
\text { System Integration, and priority applications. }\end{array}$ \\
\hline
\end{tabular}

- Municipality with a primary motivation on jurisdiction area, demography, revenue, land area, problem area, and health and emergency;

- Land area of the municipal jurisdiction and the developed area (e.g., impervious land);

- Demography or population density with sustainable transit facility and health and emergency that is pertinent to demographic dispersion and dwelling values;

- Transportation facilities viable to health and emergency, demographic patterns, and the municipal jurisdiction area;

- Health and emergency connecting demographic patterns, transit services and the problem area;

- Compliance associated with municipal jurisdiction, land coverage (developed area, developing area or pervious land, and problem area) and the environment. It necessitates the policy implications regarding environmental hotspots, availability of quality water resources, the natural resources conservation areas, and institutional and legal aspect should have given preference.

- Problem area identified as environmentally constraints or the surface breaks initially from soils associations and digital elevation models (dem) and then agro-ecological zone or physiographic unit context to determine the abundance of land suitability. On the contrary, the problem areas are the impediments for development activities such as for housing options and transit infrastructures subject to the cross-border, shared 
periphery or mixed land use.

\section{A. Multi-party Negotiation for Economic and Environmental Growth}

\section{Moratoria}

Concerning the environmental negotiation and mediation, growth management desires the Best Alternatives to Negotiating Argument (BATNA) that synchronise the interest of the municipalities to identify the best possible options clearly. The designated places concerning the growth moratoria or periphery changes need spatial data analysis to determine the effective land governance. For a municipal agency, the common traits of BATNA in principles are:

- Imposition of Criteria-based Permit System for limiting the growth rate - by supplementing a zoning control, and Transferable Development Right (TDR) Program ${ }^{66}$ to develop property under the existing Zoning Ordinance;

- Boundary or limit areas to eliminate sprawls and to protect agricultural land, development exactions and impact fees, for instance, for capital cost accumulation of sewerage treatment plants- including the New Impact Assessment Law to analyse the effects of key activities relevant to economic, environment and demographic growth before initiating implementation;

- Development moratorium does prohibit all new development require revisions of existing zoning ordinance, including tougher zoning where applicable in the case of adequate infrastructure.

\section{B. Digital Spatial Data Implementation Properties and Protocols}

The administrative boundaries of all tiers' municipalities have to have digitally enabled into two relational data models such as hierarchical data model and geo-relational data model at the same scale at the source. Administrative boundaries of municipal "dissemination area", "census tract", "municipal constituent" and "municipal agency", regional municipality and the province boundary-Census Directory, Census Year 2011. Catalogue

\footnotetext{
${ }^{66}$ Guy Greenaway \& Kimberly Good, Canadian Experience with Transfer of Development Credits and Their Potential Application to Agri-Environmental Policy. Calgary, AB: Miistakis Institute (March 2008).

${ }^{67}$ Dennis E. Gale, The Transfer of Development Rights: Some Equity Considerations, 14 Urb. L. Ann. 81 (1977), http://openscholarship.wustl.edu/law_urbanlaw/vol14/iss1/5.
} 


\section{REDRESSING THE MUNICIPAL AFFAIRS WITH 249}

No. 98-301-X2011001 ${ }^{68}$ — ought to be in one single geodata set at the same ground scale. Statistics Canada (2011) defines that Census Subdivision (CSD) is the general term for municipalities that is created by provincial legislation where the areas treated as municipal equivalents for statistical purposes, for example, Indian reserves, Indian settlements and unorganised territories or environmentally problem areas. Census Subdivisions (CSDs) are 46 types $^{69}$ according to official designations adopted by provincial or federal authorities.

Each municipality should be the operating outlet, with rigorous monitoring efforts for the shared periphery on economic and ecological disputes, as an Incremental or Phased-Approach model for spatial data implementation. Institutionally, the municipal affairs are the functional effectiveness of:

- Community and social services reconnaissance;

- Critical infrastructure development system;

- Natural resources and land use management;

- Cultural response management;

- Health and emergency planning response and recovery;

- Provisions of government funding.

Technically, the implementation of provincial digital data automation expected to be the most important integral part. In implications, OOSI would be deliverable connecting the local dissemination areas for maintaining a long-term support strategy for the operational or production transition in "land resources" and "community services", including population, housing, transits, and health and emergency. While the key aspects of land governance perused earlier, it signifies the necessity of land use delineation presumably to protect the optimal agriculture lands and rural area in the case of a new and the contemporary municipal agency with particular attention to the key aspects of land governance in the developing countries $^{70}$. Lessons learned from the provincial experience are that Ontario would need massive development of geospatial data for the community services at the public dissemination areas in threefold. First, municipal

\footnotetext{
${ }^{68}$ Statistics Canada, Census Directory, Census Year 2011, Catalogue No. 98-301-X2011001 (2011), https://www12.statcan.gc.ca/census-recensement/2011/ref/dict/98-301-X2011001-eng.pdf.

${ }^{69}$ Statistics Canada, 2001 Census Dictionary. Statistics Canada Catalogue No. 92-378-XIE, Minister of Industry, Government of Canada (2003), http://www12.statcan.ca/english/census01/Products/ Reference/dict/appendices/92-378-XIE02002.pdf).

${ }^{70}$ Shamsuddin Ahmed, The Key Aspects of Land Governance: A Policy Framework for Developing Countries, in ANNuAl World BANK CONFERENCE ON LAND AND POVERTY, The World Bank, Washington, DC, POS-07, 179 (March 2014); http://siteresources.worldbank.org/INTIE/Resources/ 475495-1378997762975/9323223-1381154375847/Agenda.pdf; and https://www.slideshare.net/ShamsuddinAhmed2/2014ahmed3839ppt.
} 
administrative review such as zoning ordinance (public notice), municipal restructuring (annexation), education, training, employment, and social expenditures (populations) and provincial finance policy (urbanisation, transportations and housing options). Second, planning policy review including brownfields inventory (community improvement plan), countryside lands (agriculture and barns), and aerial image with soils type and parcels integration (urbanisation, road networks and housing legacy). Third, environmental management review such as Greenbelt and urban forms (land, water and vegetation), and environmental hotspots and road network (local, regional and provincial profile).

\section{CONCLUSIONS}

A massive development of digital spatial data is necessary to readdress the municipal affairs toward responsible land governance. The combination of administrative data cogitates spatial features to analyse and integrate social, economic and environmental growth indicators. The Ontario One Spatial Information geodata coverage would be essential to harmonise the provincial planning needs in community services connected to the permissible land resources information for housing options and taxations categorically at the municipal dissemination area level. The outputs anticipated is to provide standard evidence as the ongoing trends for strategic planning necessities and subsequently to the policy implementation at the local municipal level abiding by the regional and provincial intergovernmental requirements towards the best alternative solution. 